\title{
Precocious, Dwarfing, and Productive-How Will New Cherry Rootstocks Impact the Sweet Cherry Industry?
}

Gregory A. Lang

Additional index words. Prunusavium, Prunus hybrids, high density, virus sensitivity, orchard management

Summary. Sweet cherries (Prunusavi um L.) can be one of the most profitable tree fruits cultivated in temperate climates. While cherry trees grow naturally to relatively tall heights $(\approx 35 \mathrm{ft}[\geq 10 \mathrm{~m}])$, new size-controlling cherry rootstocks similar to those used in high-density apple (Malusdomestica Borkh.) orchards are now a reality. The G isela (G I.) and Weiroot (W.) series from G ermany, the $G$ ran $M$ anier (G M.) series from Belgium, the P-H L series from C zech Republic, 'T abel E dabriz' from France, and others of international origin are at various stages of scientific and field testing in N orth America, with some now being used for commercial fruit production. These stocks confer several advantageous traits besides vigor control, including precocious fruiting and high productivity. While these beneficial traits are exciting, serious problems also have been documented on occasion, such as small fruit size and tree decline. As many of these rootstocks are interspecific PrunusL. hybrids, might there be significant limitations for fruit quality and orchard longevity? What is known about their tolerance to various soil types and/ or climatological stresses? What is known about their susceptibilities to pathogens and pests? F urther, with the U.S. and worldwide orchard area planted to fresh-market sweet cherries already expanding to record levels throughout the 1990s and a time-honored agricultural tendency toward overproduction until grower profits are minimized (e.g., recent international apple markets), what might be the future impact of such precocious, productive rootstocks on sweet cherry profitability and sustainable production? This overview addresses these topics, providing some answers and some areas for future scientific investigation and industry discussion.

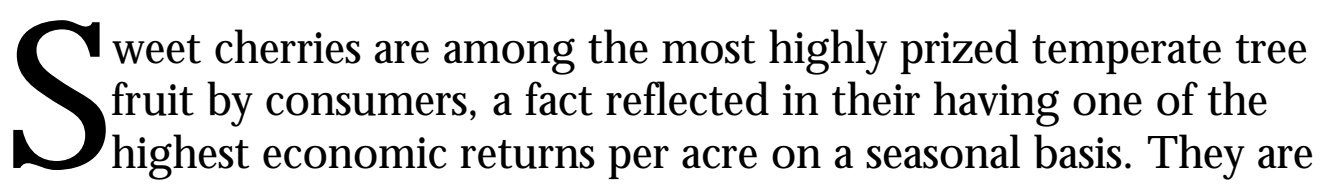
flavored intensely and, typical of Prunusspecies, can be stored for only a couple of weeks, thereby intensifying the apparent special allure (and value) to consumers due to their ephemeral availability during the summer. H owever, sweet cherries are not easy to produce, being subject to numerous serious diseases and pests (Blodgett, 1976) and susceptible to numerous vagaries of climate (severe winter cold, spring frost, rain during ripening, summer heat).

D epartment of H orticulture, Plant Science Building, M ichigan State U niversity, East Lansing, M I 48824.

The cost of publishing this paper was defrayed in part by the payment of page charges. U nder postal regulations, this paper therefore must be hereby marked advertisement solely to indicate this fact. 
Further, profitable orchard management can be challenged by the inefficiencies associated with large tree size, a long establishment period before first fruiting, and relatively small, delicate fruit, which must beharvested by hand for fresh markets. The potential production efficiencies conferred by dwarfing, precocious rootstocks havelong eluded sweet cherry growers (Toyama et al., 1964; Webster, 1996).

Beginning in the late $1980 \mathrm{~s}$, several series of promising dwarfing cherry rootstocks(Table1), developed largely from E uropean breeding and selection programs, were tested widely in N orth America (Perry et al., 1996) and Europe (Kemp and Wertheim, 1996). Some of these have shown great potential to promote precocious fruiting and high productivity, as well as provide a range of tree vigor levels to better match sweet cherries to different training systems and soil characteristics. Yet, many questions remain beforecommercial adoption of such rootstocks into high density cherry orchards is widespread, not the least of which include whether large fruit size can be attained in spite of increased crop loads, and a pervasive concern about more readily facilitating overproduction and depressing orchard economics as sweet cherries become easier to manage. With horticultural selection of this first wave of improved rootstocks occurring only recently, more advanced study of their adaptabilities, susceptibilities, and management dynamicsisstill relatively early.

\section{Sweet cherry tree vigor}

Genetic control of vigor is the driving force in the development and selection of new rootstocks for sweet cherry. Prunusavium is a forest tree in itsnativeenvironment, thereforeachallengeto maintain in an orchard. L abor to prunevigorousshoot growth and to harvest small fruit by the cluster is a major production cost madeeven more inefficient by the time spent climbing and moving ladders. Smaller trees have the potential to, at a minimum, double labor efficiency, as well as facilitate other possibleorchard efficiencies. For example, protectivechemical spray volumes can be reduced and coverage improved as tree size is decreased, benefitting both the orchard and the surrounding environment. Orchard covering systems for small trees can be developed at significantly lower costs to minimize potential damage from rain, birds, or hail. With a proper understanding of vegetative and reproductive growth relationships, small trees are easier to facilitate the even distribution of light throughout the canopy and the optimal balancing of crop loads to leaf area.

Conversely, smaller trees also present some new challenges for orchardists. With less permanent structure and less inherent vigor, balancing leaf area and storage reserves with fruiting capacity becomes more critical to achieve high quality fruit. As the proportion of the crop that can be picked from the ground increases, so doesthe vulnerability of the crop to spring frost damage. With high density orchards having open alleys between tree rows rather than a closed canopy over the tractor alley, less light interception per acre and possibly lower yields may result.

The results of about 10 years of
N C -140 (Perry et al., 1996) and other trials in $\mathrm{N}$ orth America revealed that a widerange of rootstock-influenced tree vigor is possible, from very dwarfing to very vigorous( $T$ able 2 ). I $n$ theseinitial trials, the most dwarfing rootstocks, 'Inmil' (tested as 'GM .9') from Belgium and 'Gisela 1' ('GI.1', tested as 'Giessen 172/ 9 [Gi.172/9]') from Germany, have not been satisfactory, for reasons that will become apparent later in this review. H owever, quite a few rootstocks were classified in the very useful dwarfing to semidwarfing vigor ranges, most notably ' $G I .5$ ' (tested as 'Gi.148/2') and 'GI.12' (tested as 'Gi.195/2'). In France, 'M axM a 14/ Brokforest' (a virus-free clone of ' $M x M .14$ ') has become an important semidwarfing rootstock; widespread comparative trials of the ' $M$ axM a 14' have yet to occur in either $\mathrm{N}$ orth America or Europe, though some early North American trials of 'M XM .14' have been reported (Perry, 1987). While a number of these new rootstocks equal or exceed the vigor of $M$ azzard, further evaluation has revealed some to be significantly more precocious (e.g., 'GI.6', tested as 'Gi.148/ 1'), more productive (e.g., 'GI.6', 'M XM .2'), or more adaptable to specific conditions (e.g., 'Colt' in replant sites, [Webster, 1996]) that might be of specialized interest in more traditional orchard systems.

$\mathrm{H}$ aving a range of vigor levels available to growers will likely be important for matching higher density orchard objectives with different soil typesand/ or scion variety growth habits. For instance, high density orchards of strong-growing varieties on fertile soils would be good candidates for a

T able1. C herryrootstockstested across N orth Americain the1987-88 N C -140 regional project trials(Perryetal., 1996).

\begin{tabular}{|c|c|}
\hline Prunus parentage & R ootstock \\
\hline P. avium L. & M azzard seedling (standard vigor control) \\
\hline P. avium $\times$ P. pseudocerasusL indl. & 'Colt' \\
\hline P. canescens $x$ P. avium & 'Gi.196/4' \\
\hline$P$. canescens $x$ P. cerasus & 'Gi.195/ 1' ('GI.11'), 'Gi.195/2' ('GI.12') \\
\hline P. cerasus $x$ P. avium & 'Gi.169/ 15' \\
\hline P. cerasus x P. fruticosa Pall. & 'Gi.154/ 4', 'Gi.154/ 7' \\
\hline P. x dawykensis Sealy & 'GM.61/ 1' ('D amil’) \\
\hline P. fruticosa $\times$ P. avium & ‘Gi.172/ 7’, ‘Gi.172/ 9’ ('Gl.1') \\
\hline P. fruticosa $\times$ P. cerasus & ‘Gi.173/ 9’ ('GI.10’) \\
\hline P. incisa Thunb. x P. serrulata Lindl. & ‘GM.9’ ('Inmil’) \\
\hline P. mahaleb L. & M ahaleb seedling (standard vigor control) \\
\hline
\end{tabular}


Table2.G eneral treesize( based on trunk cross-sectional area) and vigor classifications of sweet cherryon variousrootstocks, relative to that on Mazzard seedling, under irrigated conditionsin thePacificnorthwestern U nited States.

\begin{tabular}{|c|c|c|}
\hline Classification & $\begin{array}{l}\text { Relative size } \\
\text { (\% of M azzard) }\end{array}$ & R ootstock \\
\hline Very dwarfing & 35 to 50 & 'Inmil’, 'GI.1' \\
\hline Dwarfing & 50 to 65 & ‘D amil', ‘GI.5', ‘GI.7', ‘GI.8’, ‘Gi.172/ 7', ‘GI.10’ \\
\hline Semidwarfing & 65 to 80 & 'Gi.154/7', ‘Gi.169/15', 'GI.11', 'GI.12', 'C amil', 'M xM .14' \\
\hline Vigorous & 80 to 100 & M azzard, mahaleb, ‘M xM .39', ‘M xM .60', ‘GI.6', ‘Gi.196/4' \\
\hline Very vigorous & 100 to 120 & 'Colt', ‘M xM.2' \\
\hline
\end{tabular}

Table3. R ootstock classification for toleranceof or sensitivityto thepollenbornevirusesprunedwarf(PDV) or prunusnecrotic ringspot(PNRSV).

\begin{tabular}{|c|c|}
\hline Classification & R ootstock \\
\hline Tolerant & 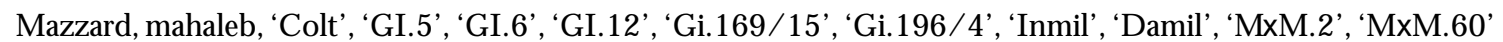 \\
\hline Sensitive & 'GI.7', 'GI.8', ‘Camil’ \\
\hline H ypersensitive & 'GI.1', 'GI.4', ‘GI.10', ‘GI.11', ‘Gi.154/4', 'Gi.154/7', 'Gi.172/ 7' \\
\hline
\end{tabular}

Table4. C herryrootstockstested across N orth Americain the1998 N C -140 regional projecttrials(K appel et al ., 1998).

\begin{tabular}{|c|c|}
\hline Prunus parentage & R ootstock \\
\hline P. avium x P. fruticosa & 'Gi.473/ 10’ ('GI.4') \\
\hline$P$. cerasus $x$ P. canescens & 'GI.5' (dwarf control), 'GI.6', 'GI.7', 'Gi.209/ 1' \\
\hline P. canescens $x$ P. avium & 'Gi.318/ 17' \\
\hline P. canescens $x$ P. cerasus & 'Gi.195/20' \\
\hline
\end{tabular}

dwarfing stock like 'GI.5', whereas moderate density orchards with otherwise similar conditions may be better planted with a semidwarfing rootstock like 'GI .12'. O n poorer soils, the high density orchard could be planted with a somewhat more vigorous stock like 'GI.12' and the moderate density orchard with a vigorousstock like'GI .6'. It should be noted that, in the NC140 trial reported by Perryet al. (1996), 'GI.6' produced full-size 'Bing' trees on fertile, irrigated soils in Washington, Oregon, and British Columbia, but produced very dwarf trees of 'H edelfingen' on poorer soilsin M ichigan and N ew York. Consequently, in addition to soil type and management factors, scion varietal differences may also have a significant impact on orchard rootstock decisions.

\section{Screening for virus sensitivity}

Whilescreening rootstocksfor susceptibilities or tolerances to various important diseases is valuable (and will be discussed further below), it has been recognized only recently that one of the earliest rootstock screening tests should be for reaction to ilarviruses, such as prune dwarf (PDV) and prunus necrotic ringspot (PN R SV). These viruses are prevalent throughout most cherry-growing regions, can be transmitted via infected pollen, and indeed are often found in sweet cherry orchardscausing no negative symptoms on trees growing on $M$ azzard ( $P$. avium) or $P$. mahaleb $L$. (mahaleb or perfumed cherry) rootstocks. H owever, some genotypes of $P$. cerasusL. ( sour cherry), P. canescens Bois. (greyleaf cherry), and P. fruticosa Pall. (steppe or ground cherry) are known to exhibit varying levels of sensitivity to these viruses, and hence so do some of the new rootstocks that have been selected or hybridized from these species. L ang et al. (1997, 1998) have shown that the virus can pass from the point of infection (young flowering shoots) to the graft union within 10 weeks, whereupon a hypersensitive rootstock may begin exuding gum, followed by yellowing and pre- mature abscission of leaves. During the second growing season following infection, hypersensitive trees collapse and die. Sensitive trees, which may only reveal a bronze leaf color during the initial season of infection, subsequently put out small, palegreen leaves and minimal new growth, which eventually lead to tree collapse and death after several growing seasons. The rootstocks that have been screened for PDV and PNRSV sensitivity thus far are listed in Table 3. I t islikely that this virus sensitivity may explain several of the cases of tree loss in the E uropean trials (Wertheim et al., 1998) that were ascribed to delayed graft incompatibility.

As there are no protective measures to be taken to halt these viruses once they infect a tree, the N C-140 regional project scientists have concluded that virustolerance should bea primary screening criteria for new cherry rootstocks. I ndeed, of the new rootstocks screened thusfar, $50 \%$ have been eliminated from further commercial consideration (Table 3 ) and 
Table5. 'B ing' sweet cherry precocity (cumulativeyield, orchard years4 to 7) and productivity (cumulativeyield, orchard years7 to 10) on four rootstockswith commercial potential (resultsfrom theN C-140 regional project trial at W ashington StateU niversity, Prosser).

\begin{tabular}{|c|c|c|c|c|c|}
\hline \multirow[b]{2}{*}{ R ootstock } & \multirow[b]{2}{*}{$\begin{array}{l}\text { Vigor } \\
\text { C lass }\end{array}$} & \multicolumn{2}{|c|}{ Precocity } & \multicolumn{2}{|c|}{ Productivity } \\
\hline & & $\begin{array}{c}\text { 4th-7th Year } \\
\text { C umulative } \\
\text { Yield [lb(kg)] }\end{array}$ & $\begin{array}{c}\text { Relative } \\
\text { Yield (\% } \\
\text { of Mazz.) } \\
\end{array}$ & $\begin{array}{l}\text { 7th-10th Year } \\
\text { Cumulative } \\
\text { Yield [lb(kg)] }\end{array}$ & $\begin{array}{l}\text { Relative } \\
\text { Yield (\% } \\
\text { of M azz.) } \\
\end{array}$ \\
\hline M azzard & vigorous & $82(37)$ & 100 & $273(124)$ & 100 \\
\hline ‘GI.5’ & dwarfing & $101(46)$ & 124 & $267(121)$ & 98 \\
\hline ‘Gl.12’ & semidwarf & $108(49)$ & 132 & 346 (157) & 127 \\
\hline ‘GI.6’ & vigorous & $174(79)$ & 213 & 405 (184) & 148 \\
\hline
\end{tabular}

Table6. Productivityand fruit quality (weight, diameter, and solublesolids) of unpruned 'R ainier' sweet cherrytreeson thed warfing rootstock ' $\mathrm{G}$ I.7', following crop load management byflower bud removal atbloom ( $5^{\text {th }}$ leaf), in an irrigated orchard at Washington StateU niversity, Prosser.

\begin{tabular}{llccc}
\hline $\begin{array}{l}\text { Crop } \\
\text { load } \\
\text { treatment }\end{array}$ & $\begin{array}{c}\text { Yield/tree } \\
{[\mathbf{l b}(\mathbf{k g}) \mathbf{]}}\end{array}$ & $\begin{array}{c}\text { Fruit } \\
(\mathbf{g})^{\mathbf{z}}\end{array}$ & $\begin{array}{c}\text { Size } \\
\text { distribution } \\
(\mathbf{\%} \geq \mathbf{2 4} \mathbf{~ m m})^{\mathbf{y}}\end{array}$ & $\begin{array}{c}\text { Soluble } \\
\text { solids } \\
\left({ }^{\circ} \mathbf{B r i x}\right)\end{array}$ \\
\hline unthinned & $43(19.5)$ & 6.9 & 49 & 21.4 \\
3 buds/ spur & $47(21.3)$ & 7.1 & 61 & 21.2 \\
2 buds/ spur & $36(16.3)$ & 9.0 & 82 & 22.7 \\
1 bud/ spur & $32(14.5)$ & 9.9 & 87 & 24.2 \\
\hline
\end{tabular}

${ }^{2} 28.4 \mathrm{~g}=1.00 \mathrm{oz}$

YF ruit diameter of $24 \mathrm{~mm}$ (0.94 inches) or larger is equivalent to 11-row or greater.

preliminary results from screening of the most recent group of rootstocks under test (Table 4) have indicated a similar percentage will be eliminated (G. Lang and W. Howell, unpublished). The new project to identify potential cherry rootstocksfrom theP. cerasus-based hybridization program at M ichigan State U niversity has made virus sensitivity screening a selection criteria that precedes any orchard testing for horticultural traits (A. I ezzoni, personal communication).

\section{Effects on precocity, productivity, and fruit quality}

Sweet cherry trees on M azzard or mahaleb rootstocksoften do not flower significantly until the $6^{\text {th }}$ or $7^{\text {th }}$ leaf. Some of the new hybrid rootstocks begin flowering in the $3^{\text {rd }}$ leaf $\left(2^{\text {nd }}\right.$ year in the orchard), with economic crop potential in the $4^{\text {th }}$ to $5^{\text {th }}$ leaf. Such precocity is a tremendous economic advantage, helping to recover orchard establishment costs much earlier and thereby advancing the financial breakeven point in the life of the orchard by several years. In the 1987 N C-140 trial, the Gisela rootstocks were the most precocious, with first flowering ranging from the $3^{\text {rd }}$ to the $5^{\text {th }}$ leaf (Perry et al., 1996). The Gran $M$ anier rootstocks were not quite as precocious, averaging about a year longer, followed by mahaleb and the $M \times M$ rootstocks, $M$ azzard, and ' $C$ olt'. While the most vigorous rootstocks generally were the least precocious, 'GI.6' exhibited strong vigor in the Pacific northwestern U.S. yet was as precociousasthemoredwarfing ' $G I .5$ ' and 'GI.7' (tested as 'Gi.148/ 8'). A measure of precocity for three virustolerant Gisela rootstocks having different vigor classesin Washington state, compared to M azzard, can be determined from the cumulative yieldsover years 4 to 7 in the orchard (Table 5). For full-size 'Bing' trees on ' $G$ I.6', the cumulativeyieldsweremorethan twice that of trees on M azzard, and even trees on the semidwarfing ' $G I .12$ ' and dwarfing ' $G I .5$ ' had yields about 25\% to $30 \%$ higher, on a per tree basis. Planting such rootstocksat higher densities to best utilize their reduced size will increase early yields, on a per acre basis, even more.

In addition to earlier formation of flower buds, theprecocious $\mathrm{G}$ iselarootstocks also promote a higher number of flowering nodes and ultimately higher spur formation. This results in the potential for continued high productivity, compared to M azzard, even after the impact of precocious flowering is factored out. The Productivity column in Table 5 reveals the higher yields possible during orchard years 7 to 10 on the three Gisela rootstocks currently recommended for commercial trial. Yields were similar, on a tree basis, between the dwarf treeson ' $G$ I.5' and the full-size trees on M azzard, yet in commercial orchardsthe dwarf trees would be planted at up to twice the density of thefull sizetrees. This bodes well for maintaining good production levels even as some reduction in total light interception per acre may be expected due to open alleys in high density orchards. The semidwarfing and vigorous $\mathrm{G}$ isela rootstocksmaintained yields of about $25 \%$ and $50 \%$ higher than $\mathrm{M}$ azzard, respectively. These productivity traits can be used to particular advantagein promoting higher crop loads on lighter-bearing varieties like 'Tieton' and 'Cavalier'.

With respect to rootstock influence on fruit quality - a matter of critical importance as worldwide cherry production increases market competition-in the N C - 140 trials, the largest fruit size generally was attained from the most vigorous trees. A caveat to this parameter is that the management of trees in the N C-140 trials was relatively minimal, in order to document natural rootstock influences without the impact of horticultural management. Since balancing crop loads to leaf area is a critical factor in sweet cherry fruit size variation, potential genetic and physiological effects of rootstocks on fruit size can only truly be examined by comparative experimentsthat tightly regulateleaf-to-fruit ratiosacrossrootstock genotypes (such trials are now underway).

O bservations and interpretations of the N C-140 data during years in 
Table7. C herry rootstocksnow being screened for virussensitivity and potential inclusion in thenext N orth American N C -140 regional projecttrial.

\begin{tabular}{lll}
\hline Parentage & Origin & Designation \\
\hline P. avium x [P. canescens x P. kurilensis (M iyabe) Wils. ] & Germany & 'PiKu 4.11', 'PiKu 4.13', 'PiKu 4.15' \\
P. avium x [P. canescens x P. tomentosa Thunb.] & Germany & 'PiKu 4.17', 'PiKu 4.20' \\
P. avium x P. cerasus & Czech Republic & 'P-H L A', 'P-H L B', 'P-H L C' \\
P. cerasusx [P. cerasus x P. maacki Ruprecht] & Russia & 'LC-52', 'VC-13' \\
P. fruticosa x P. serrulata va. lannesiana Carrière & Russia & 'VSL-2' \\
P. serrulata var. lannesiana & 'Lussia & 'PiKu 4.83' \\
P. pseudocerasusx [P. cansecens x P. incisa] & Germany & 'Bz-3-II' \\
Unknown & Russia &
\end{tabular}

which spring frosts altered crop loads, however, lead to some preliminary conclusions regarding rootstock effect on fruit size. Fruit from treeson 'I nmil', and sometimes 'Damil' (tested as 'GM.61/1') and 'Camil' (tested as ' $G M .79^{\prime}$ ), most often were noted across all sites and across various years to be smaller than fruit on the other rootstocks (Perry et al., 1996). Fruit from trees on the $\mathrm{G}$ isela rootstocks generally were smaller than fruit on $M$ azzard in heavy cropping years, but similar in size (except for 'GI.1') to fruit on Mazzard when crop loads weremoderated by spring frost. $\mathrm{H}$ ence, the hypothesis that good fruit size can be attained, even on these highly productive rootstocks, via intensive orchard management remains valid and in need of proof. A preliminary study ( $L$ ang and $O$ phardt, 2000) that thinned flower budsjust before bloom to alter crop loads on unpruned trees of a very productive variety, 'R ainier', on a very productive dwarfing rootstock, 'GI .7', resulted in highly significant differences in fruit size, yet respectable yields ( $T$ able 6 ). C ompared to the control crop load, which was similar to those under low management in the N C -140 trials, altering the crop by leaving 1 or 2 flower buds per spur reduced total yields by up to $25 \%$, but increased fruit size by up to $43 \%$ Fruit were of higher flavor quality as well, with significantly higher soluble solids, and up to $87 \%$ of the crop was packable for fresh markets compared to only half the crop of the unthinned control. O $\mathrm{n}$ a per acre basis, the minimally managed trees would have yielded about 3.5 tons ( $3.2 \mathrm{t}$ ) of marketable fruit, whilethe crop load-managed trees would have yielded about 5 tons ( $4.5 \mathrm{t}$ ) of marketable fruit, a significant achievement in the $5^{\text {th }}$ leaf.

Thus, the challenging aspect to those new rootstocks that are both precocious and highly productive is that overcropping is a strong possibility as early as the $5^{\text {th }}$ leaf, before a typical tree on M azzard would even have a crop. Yet, in the case of those rootstocks from this first wave that are being recommended for grower trial ('GI.5', 'GI.6', and 'GI.12'), this does not appear to beagenetic limitation of therootstock, but rather achallengeto develop new ways to manage cherry orchards now that precocity and excessive vigor are less of a problem. $M$ atching varieties and training and management systemsto rootstock traits is therefore likely to become more important as the number of suitable rootstocksand their diversity of unique traits offers growers a greater set of orchard tools from which to choose.

\section{Soil and climatic adaptations}

In general, seedling rootstocks like $M$ azzard and mahaleb are deeprooted and tolerate drought conditions better than clonally propagated rootstocks that tend to be more shallow-rooted. This may be the reason 'C olt' is considered semidwarfing under nonirrigated conditions, as often occursin E uropean orchards, while on the irrigated fertile loam soils of the western U.S., it can be at least as vigorous as M azzard. 'Colt' also appears to be less vigorous on clay soils (R. Perry, personal communication). H owever, some of the MxM series, which arepropagated clonally, develop extensive root systems (such as M XM .2 and $\mathrm{M} \times \mathrm{M} .60$ [L ongstroth and Perry, 1996]) and have been noted to be drought-tolerant (Wertheim, 1998). Rootstocks derived from $P$. cerasus tend to have shallow roots and are sensitive to drought, such as 'T abel Edabriz' (Webster, 1996). The P. avium $\times P$. cerasus hybrid rootstocks from the Czech Republic, 'P-H L A',
'P-HL B', and 'P-HL C', also are sensitiveto drought (Wertheim, 1998). Experience at Washington State U niversity with inadvertent irrigation problems in one trial block suggests that 'GI.1', 'GI.5', and 'GI.7' are fairly sensitive to drought stress. The Russian rootstocks 'L-2', 'LC-52', 'VC13 ', and 'VSL-2' were selected under nonirrigated conditions and are presumed to drought tolerant, though they are noted to perform poorly on rocky soils (G. Eremin, personal communication).

As for some of the other species that have been used to create new cherry rootstocksthrough selection or hybridization, $P$. canescens and $P$. cer asustend to have shallow roots and are sensitive to anaerobic conditions, though some deep-rooting has been found (Perry, personal communication). Although the P. cerasus-based Weiroot series are recommended for well-drained soilsnot subject to flooding (Wertheim, 1998), P. cerasus in general has been reported to be quite tolerant of heavy soils (Perry, 1987). $P$. fruticosa has shallow roots and is somewhat tolerant of anoxia. With regard to specific rootstocks, 'Colt' and 'D amil' are reported to be somewhat tolerant of anoxia, as are ' $\mathrm{GI} .4$ ' (tested as 'Gi.473/ 10'), 'Gl.6', and 'Gi.169/ 15' (ASH S, 1997; FrankenBembenek, 1996; Webster, 1996). 'Gi.196/4' does not tolerate anoxia well. The Russian rootstocks noted above are reported to tolerate heavy soils and excessive soil moisture (G. Eremin, personal communication).

There has been very little N orth American research on rootstock interactions with different soil chemistries. The Belgian rootstocks, 'Inmil' and 'D amil', as well as 'Colt' and 'T abel Edabriz', are sensitive to calcareous, high $\mathrm{pH}$ soils, whereas $\mathrm{P}$. mahalebbased rootstocksarewell-suited to such 
soils (ASH S, 1997; Callesen, 1998; Webster, 1996). C allesen (1998) summarized several reports that ' $\mathrm{C}$ olt' and 'D amil' take up nitrogen and potassium poorly, one of which (Ystaas and Froynes, 1998) also showed that trees on ' $\mathrm{Gl} .1$ ' had low $\mathrm{N}$ and trees on 'Colt' also had lower $P$ levels and higher levels of leaf $\mathrm{C}$ a and $\mathrm{M} \mathrm{g}$. Some of these reports are contradictory, requiring morestudy beforemany useful conclusionscan bemade. O f particular interest, in the matter of soil relations, is the tolerance of ' $C$ olt' to replant disease (Webster, 1996), which normally causes decline and, possibly, death of young trees on M azzard or mahaleb that havebeen planted on old cherry orchard soils.

Cold hardiness tests conducted by Strauch and Gruppe (1985) revealed good hardiness of $P$. avium selections from mountainous regions, $P$. cerasus $x P$. subhirtella $M$ iq., $P$. mahaleb ['St. Lucie 64' ('SL.64')], 'GI.6', 'GI.8' (tested as 'Gi.148/ 9'), 'GI.12', and 'Gi.196/4'. Cumminset al. (1986) found good early winter hardiness with 'GI.6' and 'GI.10', but mixed results with ' $G I .11$ ' (tested as 'Gi.195/ 1') and 'GI.12'. Strauch and Gruppe (1985) rated 'GI.5' as similar in hardiness to the ' $F .12 / 1$ ' clone of $M$ azzard, though Cummins et al. (1986) found 'GI.5' to be very coldhardy with respect to early winter freezes. Lang et al. (1997) reported that Bing flower buds on ' $G I$.5' were equally hardy to those on seedling $M$ azzard in January, but that deacclimation occurred more rapidly on 'GI.5' during February and $M$ arch, a characteristic also evident in the data of Strauch and Gruppe(1985). 'GI .6', 'GI.8', 'GI.12', and 'Gi.196/4' remained similarly hardy in J an and Feb, with slightlyaccelerated deacclimation in $M$ arch (but not as much as 'GI.5'). L east hardy is 'Colt', for both early winter and midwinter freezes (Strauch and Gruppe, 1985; Cummins et al., 1986; Perry et al., 1996). This would suggest caution in planting ' $\mathrm{P}-50$ ' (Table4), which appears to be derived from $P$. pseudocerasus $L$ indl. (false cherry), in climates with potentially severe winter cold until it can be evaluated accordingly. In addition to losing several trees on 'C olt' to a severe D ecember freeze, the NC-140 trial in U tah also lost treeson 'C amil', 'D amil', 'Inmil', and 'Gi.196/4' (Perry et al., 1996).

\section{Other disease sensitivities}

L ittleresearch hasbeen conducted on the disease susceptibilities of these new rootstocksin $\mathrm{N}$ orth America, with the exception of bacterial canker (Pseudomonassyringaepv. syringaevan $\mathrm{H}$ all) (Krzesinska and Azarenko, 1992), Phytophthora (see below) and Armillaria (see below) root rots (Cummins et al., 1986; Proffer et al., 1988), and the ilarvirus sensitivity described above( $L$ ang et al., 1997, 1998). While the severity and longevity of bacterial canker infections vary with climate and can sometimes be managed, selection of rootstocks that are less susceptible is a high priority in certain areas like 0 regon's Willamette valley. Cherry rootstocksthat havebeen reported previously (ASH S, 1997; Webster, 1996; Wertheim, 1998) to be somewhat tolerant or less susceptible to bacterial canker include the vigorous rootstocks ' $\mathrm{F} .12 / 1$ ', 'Colt', and the $M X M$ series, although only 'Charger' ( $P$. avium) is noted to be "resistant". Krzesinska and Azarenko (1992) found 'GI.10' (tested as 'Gi.173/9') and 'Gi.169/ 15' to be more sensitive to bacterial canker than 'F.12/ 1'; 'GI.5' and 'GI.6' were similar in susceptibility to ' $F .12 / 1$ '.

Avoidance of root rot caused by infection with Phytophthora megasperma D reschler, $P$. cambivora (Petri) Buisman, P. drechsleri Tucker, P. cryptogea Pethyb. \& Laf., P. cinnamomi R ands, P. citricola Sawada, $P$. syringae (Kleb.) Kleb., and $P$. cactorum (Lebert \& Cohn) Schroet. is important in many California and eastern U .S. cherry growing areas (M ink and Jones, 1996). Some resistance to Phytophthora root rots has been reported for the MxM series, 'Damil', 'GI.10', and 'Gi.169/ 15' (C ummins et al., 1986). The seedling-derived $P$. mahaleb rootstockscommon in N orth America are known for being sensitive to various Phytophthora sp., and tests have suggested the following are also sensitive: 'I nmil', 'Camil', 'GI.1', 'GI. 6', 'GI.11', 'GI.12', 'Gi.196/4', and several new $\mathrm{H}$ ungarian mahaleb seedling selections (CT500 and CT 2753) that are just now entering trials in N orth America (Wertheim, 1998).

Resistanceto Armillaria root rots, caused by Armillaria mellea sensu stricto(Vahl ex Fr.) Kummer, A . ostoyae (Romagn.) H erink., and/ or A . bulbosa (Barla) Kile \& Watling, would be an important rootstock trait in cherrygrowing regions of $\mathrm{M}$ ichigan and on other sandy soils in eastern North A merica(M ink and J ones, 1996). Some reports (Proffer et al., 1988; ASH S, 1997; Webster, 1996) have indicated sensitivity to Armillaria by 'Colt', 'Inmil', 'M xM.2', 'Gi.196/4', mahaleb seedling, and someP. cerasus derived rootstocks, with lesssensitivity by M azzard, 'GI.11', and ' $M$ XM .60'.

Wilt caused by Verticillium dahliaeK leb. can be a problem in parts of Washington state where Verticillium-harboring cropssuch as potatoes (Solanum tuberosum L.) and mints (M entha sp. L.) are prevalent. There has been little or no research conducted on rootstock tolerance to verticillium wilt. Likewise, little work has been done on crown gall [A grobacterium tumefaciens (E.F. Smith \& Townsend) Conn.] susceptibility or resistance, with notes only on tolerance exhibited by ' GI .10' and sensitivity exhibited by 'F.12/ 1', 'Colt', N orth American seedling mahaleb, the $\mathrm{H}$ ungarian mahalebs (CT500, CT 2753), 'D amil', and 'Gi.196/ 4' (ASH S, 1997; Webster, 1996; Wertheim, 1998). Western $X$ disease, caused by leafhopper-transmittal of a mycoplasma-like organism (MLO), causes a slow decline in trees on M azzard and 'Colt', and a rapid decline on mahaleb due to a hypersensitive resistant response that preventstransmittal of the M L O from the infected scion into the rootstock (U yemoto et al., 1991). All of the G isela rootstocks and 'D amil' were as susceptible to Western $X$ disease as $M$ azzard, while ' $M \times M .2$ ' and 'M XM .46' exhibited responses similar to mahaleb.

\section{Conclusions}

The first wave (Table 1 ) of new sweet cherry rootstocks for North American trial has yielded at least 3 precocious, highly productive genotypes('GI.5', 'GI.6', and 'GI .12') with differing vigor levelsworthy of grower trial in more intensive orchard management strategies. The outstanding productivity of some very vigorous rootstocks, like 'M XM .2', also may be worthy of trial by growersinterested in more traditional orchard systems. The precocity of the next wave (Table 2 ) will become evident in 2000-01, and the virus sensitivity of the second and third (Table 7) waves will also become known during thenext couple of years. 
These regional and institutional trials hold great promise for discovering new traits that progressive cherry growers may utilize to meet some of the production challenges of the future.

Sweet cherry production is bound to undergo significant change in the new millennium, with adiversity of new rootstock traitsaltering the foundations of orchard management that changed little during the $20^{\text {th }}$ century. The induction of precocious cropping is an extremely strong economic incentive that will become common, via either rootstocks or new cultural manipulation of standard rootstocks, to remain competitive as orchard capitalization costs increase. Similarly, smaller tree stature and higher density orchards will become common as experience in crop load management on highly productive, vigor-controlling rootstocks increases. Rather than focus management decisions on minimal early pruning to hasten cropping and later pruning to manage excessive vigor, as are current practices, high quality intensive cherry orchards likely will be pruned and fertilized moreaggressively throughout their existence to generate new leaf area and balance cropping potential, resulting in a more labor efficient orchard that can also be better protected from some of the many risks inherent in sweet cherry production.

As dwarfing, precocious rootstocks have revolutionized apple production in N orth America and worldwide, the late 1990s have seen concomitant apple production levels in North America, New Zealand, Europe, and China outpace market demand, with disastrous effects on sustainableprofits. Sometraditional cherry growers have expressed concern that rootstocks which confer greater orchard efficiency and ease of production may lead this currently profitable industry down similar paths. The history of modern agriculture suggests that eventual overproduction isalmost an inherent outcome of a free market system comprised of independent producers. Certainly, any orchard innovation that promotes more sustainable production in amilieu typically subject to numerous serious climatic and pathological challenges will make production of that commodity more attractiveto new growersand/ or expansion by existing growers, and hence require greater planning and/ or partnering between producers and marketers to better balance demand with anticipated supplies. H owever, it also is clear that the future of laborintensive traditional sweet cherry production cannot be sustained in N orth America and Europe as agricultural labor forcescontinueto concomitantly shrink and become more expensive. In thelogical hierarchy of sustainable production challenges, high density labor-efficient orchards (based on acombination of improved rootstock genetics and more intensive management) will clearly be a factor in maintaining the potential economic viability of $\mathrm{N}$ orth A merican sweet cherry production. Grower-packer-marketer communication and coordination to anticipate market demand and possible saturation will clearly be related, but separate, factors.

\section{Literature cited}

ASH S. 1997. The Brooks and O Imo register of fruit and nut varieties. ASH S Press, Alexandria, Va., p. 213-216.

Blodgett, E.C. 1976. Why cherry trees die. Wash. State Univ. Coop Ext. Bul. 668, Pullman, Wash.

Callesen, O. 1998. Recent developments in cherry rootstock research. Acta Hort. 468:219-228.

Cummins, J.N., W.F. Wilcox, and P.L. Forsline. 1986. Tolerance of some new cherry rootstocks to $D$ ecember freezing and to Phytophthora root rots. Compact Fruit Tree 19:90-96.

Franken-Bembenek, S. 1996. The G iessen cherry rootstocks. Compact Fruit Tree 29:19-36.

Kappel, F., G. Lang, R. Perry, and R. Andersen. 1998. A new N C-140 regional cherry rootstock trial for 1998 . A cta H ort. 468:241-247.

Kemp, H . and S.J. Wertheim. 1996. First results of two international cherry rootstock trials. Acta H ort. 410:167-176.

Krzesinska, E.Z. and A.N.M. Azarenko. 1992. Excised twig assay to evaluate cherry rootstocks for tolerance to Pseudomonas syringaepv. syringae. H ortScience 27:153155.

Lang, G., W. H owell, and D. Ophardt. 1998. Sweet cherry rootstock/ virus interactions. Acta H ort. 468:307-314.

L ang, G., W. H owell, D. O phardt, and G. M ink. 1997. Biotic and abiotic stress responses of interspecific hybrid cherry rootstocks. Acta H ort. 451:217-224.

Lang, G.A. and D. O phardt. 2000. Inten- sive crop regulation strategies in sweet cherries. Acta H ort. 514:227-234.

Longstroth, M. and R.L. Perry. 1996. Selecting the orchard site, orchard planning and establishment, p. 203-222. In: A.D. Webster and N.E. Looney (eds.). Cherries: Crop physiology, production, and uses, CAB I nternational, Oxon, U.K.

M ink, G.I. and A.L. Jones. 1996. Cherry diseases: their control and prevention, $\mathrm{p}$. 347-366. In: A.D. Webster and N.E. L ooney (eds.). Cherries: Crop physiology, production, and uses, CAB International, Oxon, U.K.

Perry, R.L. 1987. Cherry rootstocks, p. 217-264. In: R.C. Rom and R.F. Carlson (eds.). Rootstocks for fruit crops, John Wiley \& Sons, N ew York.

Perry, R ., G . L ang, R . Andersen, L . Anderson, A. Azarenko, T. Facteau, D. Ferree, A. Gaus, F. Kappel, F. M orrison, C. Rom, T. Roper, S. Southwick, G. Tehrani, and C. Walsh. 1996. Performance of the N C-140 cherry rootstock trials in $\mathrm{N}$ orth America. Compact Fruit Tree 29:37-58.

Proffer, T.J., A.L. Jones, and R.L. Perry. 1988. Testing of cherry rootstocks for resistance to infection by species of Armillaria. Plant D isease 72:488-490.

Strauch, H . and W. Gruppe. 1985. Results of laboratory testsfor winterhardiness of $P$. avium cultivars and interspecific cherry hybrids (Prunus $x$ spp). Acta Hort. 169:281-287.

Toyama, T.K., H .W. Fogle, E.L.Proebsting, Jr., E.C. Blodgett, and M.D. Aichele. 1964. Three-year production recordsfrom acherry rootstock study. Proc. $60^{\text {th }}$ Wash. State H ort. Assn., p. 119-120.

U yemoto, J.K., B.C. Kirkpatrick, and J.N . Cummins. 1991. Susceptibility of selected cherry clones and related species to Western X-disease. H ortScience26:1510-1511.

Webster, A.D . 1996. R ootstocksfor sweet and sour cherries, p. 127-163. In: A.D. Webster and N .E . L ooney (eds.) . C herries: Crop physiology, productions and uses, CAB International, Oxon, U.K.

Wertheim, S.J. 1998. Rootstock guide: Apple, pear, cherry, european plum. Fruit Res. Sta. Publ. 25, Wilhelminadorp, The N etherlands, p. 85-114.

Wertheim, S.J., J.M.T. Balkhoven, O. Callesen, J. Claverie, J. Vercammen, J. Ystaas, and S. Vestrheim. 1998. Results of two international cherry rootstock trials. Acta H ort. 468:249-264.

Ystaas, J . and O . Frøynes. 1998. The influence of eleven cherry rootstocks on the mineral leaf content of major nutrients in 'Stella' and 'U Ister' sweet cherries. Acta H ort. 468:367-372. 